\title{
The Impact of Za'atari Refugee Camp on the Water Quality in Amman-Zarqa Basin
}

\author{
Sura Al-Harahsheh ${ }^{1 *}$, Rida Al-Adamat ${ }^{2}$, Seraj Abdullah1 \\ ${ }^{1}$ Institute of Earth and Environmental Science, Al Al-Bayt University, Mafraq, Jordan \\ ${ }^{2}$ Department of Surveying Engineering, Faculty of Engineering, Al Al-Bayt University, Mafraq, Jordan \\ Email: surah h71@yahoo.com
}

Received 15 December 2014; accepted 28 December 2014; published 14 January 2015

Copyright (C) 2015 by authors and Scientific Research Publishing Inc.

This work is licensed under the Creative Commons Attribution International License (CC BY). http://creativecommons.org/licenses/by/4.0/

(c) (i) Open Access

\begin{abstract}
Za'atari camp is the largest refugee camp in Jordan. It was first established in 2012 to host Syrian refugees. Currently the camp hosts more than 81,000 refugees, with no proper sanitary system which might pose a major threat to surface resources in the area. An investigation was done at Za'atari refugees' camp to find the impact of refugees settling on surface and groundwater quality. Surface water quality of surface runoff generated from thirty rain fall events were collected during the winter season of $2013 / 2014$ from the major Wadi that passes through the camp and small ponds within the camp after the rainfall event. The collected samples were analyzed for acidity $(\mathrm{pH})$, the electrical connectivity (EC), total dissolved solids (TDS), nutrients ( $\mathrm{NO}_{3}^{-}$and $\mathrm{PO}_{4}^{3-}$ ) and selected heavy metals ( $\mathrm{Mn}, \mathrm{Cd}, \mathrm{Zn}, \mathrm{Pb}$ and $\mathrm{Ni}$ ) in addition to biological oxygen demand (BOD5), chemical oxygen demand (COD) and intestinal worms (Total Coliform, E. cali). The results showed that there are significant variations in the EC as well as with TDS between the sites due to fluctuating amounts of water used for different activities within the camp as it was highest in the center of the camp where most of the refugees settle decreasing away from the center. The $\mathrm{pH}$ values were within the specifications of the World Health Organization and the Jordanian Standards. For nutrients, nitrate concentration was low with high phosphate ions which are most probably from detergents origin.
\end{abstract}

\section{Keywords}

Jordan, Refugee, Za'atari Camp, Amman-Zarqa Basin, Heavy Metals

\section{Introduction}

Za'atari camp is the largest refugee camp in Jordan. It was first established in summer of 2012 to host more than

${ }^{*}$ Corresponding author.

How to cite this paper: Al-Harahsheh, S., Al-Adamat, R. and Abdullah, S. (2015) The Impact of Za'atari Refugee Camp on the Water Quality in Amman-Zarqa Basin. Journal of Environmental Protection, 6, 16-24.

http://dx.doi.org/10.4236/jep.2015.61003 
81,000 Syrians fleeing the violence in the ongoing Syrian civil war that erupted in 2011. The camp lacks proper sanitary system and depends on primitive cesspools within the camp after passing through small ditches and lagoons between the Caravans and tents and was evacuated periodically through septic tanks away from the camp polluting the surface and groundwater of the camp site.

Impact of cesspools on ground and surface water quality was investigated in many parts of the world. In Jordan, Tarawneh et al. [1] investigated the chemical and biological quality of spring at Tafila region. It was found that there was no impact of cesspools on groundwater quality due to scatter distribution of these cesspools in the area.

Al-Kharabsheh [2] found that cesspools not connected to the sewer system at Wadi Kufranja basin, Jordan are considered to be the main cause of water pollution in this area.

Impact of human activity of surface and groundwater resources at Amman-Zarqa area was reported by Alsagrat [3]. It was found that the high concentrations of nitrates, phosphate and ammonium are due to wastewater originated from many sources such as factories, septic tank and other human activities. Water quality of groundwater from NE of Al-Mafraq city was reported by Alzoubi [4]. It was found that the EC ranged from $286 \mu \mathrm{S} / \mathrm{cm}$ to $4890 \mu \mathrm{S} / \mathrm{cm}$. Chemical and microbial quality of drinking water in Al-Mafraq area was investigated by Al-Ani [5]. It was found that the analyzed water samples were safe in terms of microbial content as the functional and pathological bacteria were not found in the collected samples. Al-Harahsheh et al. [6] studied the chemical evolution and its indicators in the quality of drinking water from source to the consumer in Al-Mafraq and Al-Zarqa Governorates. Al-Mafraq and Al-Zarqa cities were chosen to study the chemical evolutions in drinking water during its distribution journey in distributed networks from source to consumer; to study causes and the ways they occur as well as the wells that support them. The study showed that the standards of this water were identical to Jordanian Standards and World Health Organization guideline. There was no biological pollution except in Al-Hussien suburb in Al-Mafraq city as it was discovered that there was a leak in the public sewage network, next to the house's reservoirs where pollution found.

This work aims to investigate the impact of settlement at Za'atari refugee camp and its surrounding villages on the surface water quality in terms of it chemical and biological content which might lead to the deterioration of groundwater quality in these areas.

\section{Study Area}

The study area is located to northeast of Al-Mafraq governorate at the northern part of Amman-Zarqa basin. Before 2011 the area was lack of any anthropogenic activities but the start of Syrian civil war it was occupied with refugees reaching 81,000 refugees in 2014 releasing various types of pollutants to the surrounding areas due to their daily activities. The investigated site is around $19 \mathrm{~km}^{2}$ (Figure 1(a) and Figure 1(b)) and characterized by arid to semi arid climatic conditions with semi flat topography. Within the investigated site there are small valleys passing through the camp area draining winter rain during pluvial seasons which extends from November to April.

The distances between the sampling sites ranged from $500 \mathrm{~m}$ to $700 \mathrm{~m}$ depending on location of water pond after the rainfall events.

\section{Methodology}

\subsection{Data Collection}

Surface water samples were collected during the rainfall season 2013-2014. Sampling campaign was done after each rain fall events from ten sites within and surrounding the camp area. Two samples were at the northern edge of the vamp, six sites were within the camp area and two sites from the effluent water discharging from the camp area. Location map of these sites are shown in Figure 2. The selected sites were restricted to the western part of the camp due to security reasons, where researchers were not allowed to cover the entire camp.

For heavy metals, the surface water samples were collected directly after rainfall using PVC containers and few drops of $\mathrm{HNO}_{3}$ was added to prevent precipitation of heavy metals during transportation of the samples to the laboratory. For nutrient ionic composition, one liter of PVC bottles were used after being washed with distilled water based on adopted standards in American Public Health Association [7]. For microbial analysis, 200 $\mathrm{ml}$ glass bottles were sterilized using autoclave at $120^{\circ} \mathrm{C}$ for 20 minutes after being washed with potassium dichromate powder and hot water and washed with distilled water [8]. One $\mathrm{mL}$ of $3 \%$ sodium thiosulfate solu- 


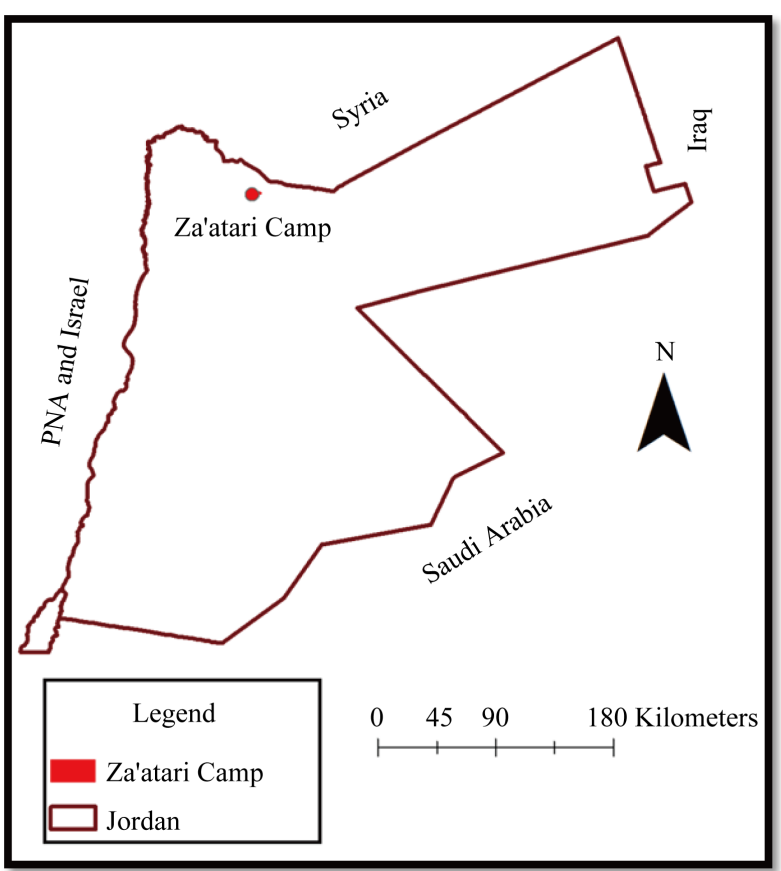

(a)

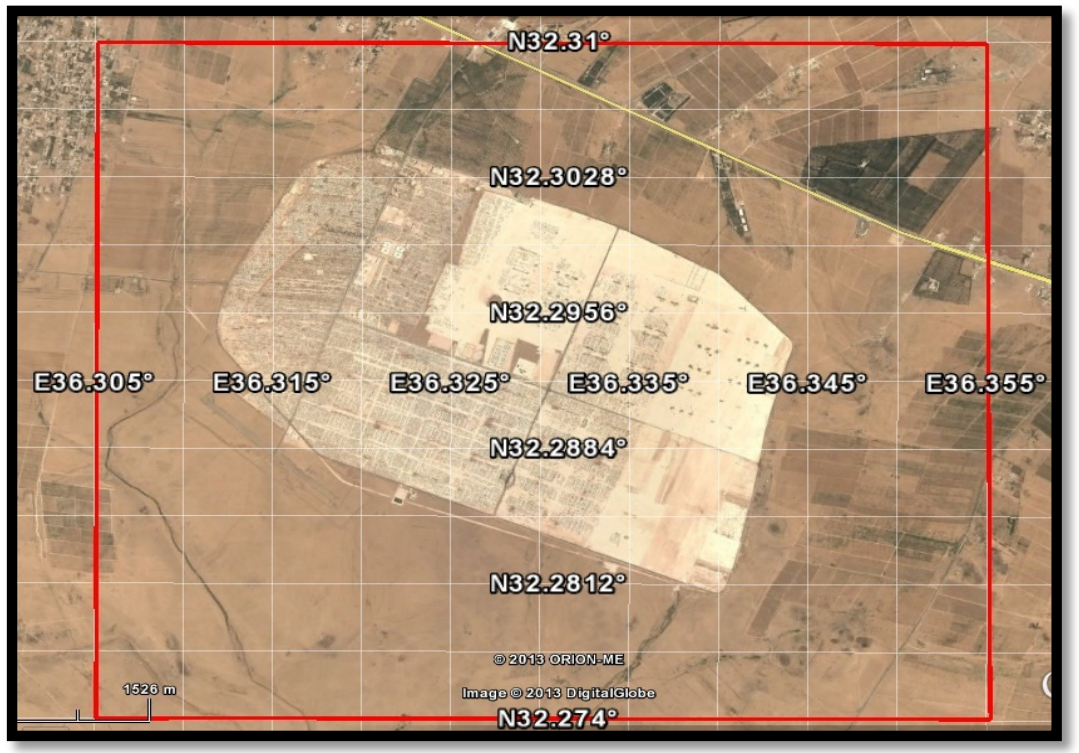

(b)

Figure 1. (a) Za’atari Camp within Jordan; (b) Za’atari Camp (Google Earth, 2013).

tion was added to each container before starting sterilization process to remove any chlorine residue which can oxidize the microbes exist in the collected samples as shown in the following reaction

$$
\mathrm{Cl}_{2}+2 \mathrm{NaS}_{2} \mathrm{O}_{3} \rightarrow \mathrm{Na}_{2} \mathrm{~S}_{4} \mathrm{O}_{6}+2 \mathrm{Cl}
$$

\subsection{Data Analysis}

For each site and period, $\mathrm{pH}$ and electrical conductivity was measured on site using WTW conductivity meter (LF 320) and WTW 525. For $\mathrm{NO}_{3}^{-}$and $\mathrm{PO}_{4}^{3-}$ spectroscopic methods was used using spectrophotometer (Camlab Company, UK) at wave lengths $206 \mathrm{~nm}$ and $690 \mathrm{~nm}$ respectively. For heavy metals (Cd, Mn, Ni, and 


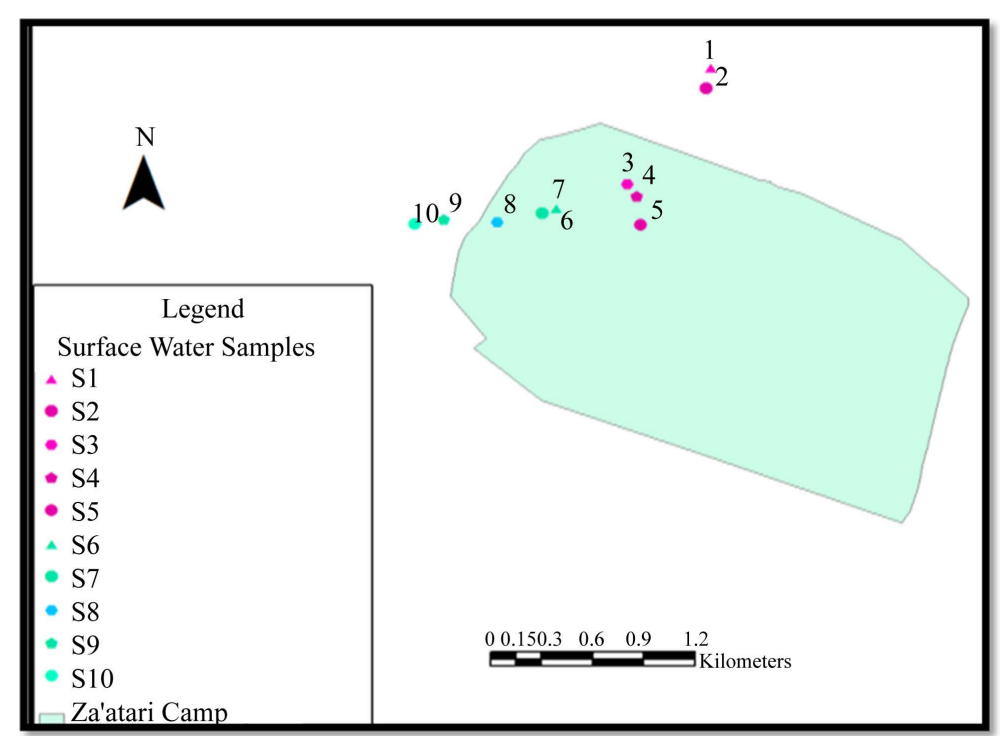

Figure 2. Location map of sampling sites.

Zn were determined by Ionic Atomization using Varian 800 AA with deuterium lamp background correction after acidified the water samples by a few drops of $\mathrm{HNO}_{3}$. For biological Oxygen Demand (BOD) was 5 day BOD test (Ref. WW-BOD 5 -R003). For Chemical Oxygen Demand was using Closed Relux Titration Method (Ref. WW-COD-R005).

Bacterial test is done by two tests for each sample in terms of specifying and counting the Total Coliform and E. coli, through using Defined Enzyme Technology (DET) by taking $100 \mathrm{ml}$. of the sample to be tested in a sterilized glass bottles and then adding Colilerr-18 as an enzyme working on defining Total Coliform and $E$. coli. After mixing the sample with added enzyme, it was placed in Quanti Tray 2000. After that, it was pulled out by Sealer Zx Quanti-Tray in order to be ready to incubate at a temperature of $35^{\circ} \mathrm{C}$ for $18-22$ hours. The yellow color determines the Total Coliform and by using Ultraviolet light at a wavelength of $365 \mathrm{~nm}$ determining E. coli (Standard Methods, 2012).

\section{Results and Discussion}

\subsection{Chemical Analysis Results}

Table 1 shows the average chemical composition of the collected water sample from different sites within the study area. The acidity of the water samples as illustrated in Figure 3 showed an increase in alkalinity with the flow of water inside the camp. This can be attributed to the buffering effect of carbonates rocks of the area and not due to the anthropogenic activities of the camp. The total dissolved solids showed a wide variation between the sampling sites as it ranged from $231 \mathrm{ppm}$ from sites before the surface runoff enters the camp to $1200 \mathrm{ppm}$ in sites within the camp decreasing to $400 \mathrm{ppm}$ for the water discharging from the camp area (Figure 4). The variations can be attributed to no anthropogenic activities at the influent site before the surface runoff enters the camp area increasing with its flow inside the camp as the highest concentrations were at the end of the camping area then diluting with mixing of the rainfall with the effluent out of the camp area. Within the camp area there was a variation in salinity which can be attributed to variation in number of inhabitants and the human activities diversity at different places in the camp.

For nitrates and phosphate the highest concentrations were found inside the camp area (Figure 5) which are due to daily anthropogenic activates of the people living inside the camp. However, the highest concentration was detected at the mouth of the effluent water discharging from the camp and the lowest at area outside of the camp area where no anthropogenic activities exists. $\mathrm{PO}_{4}^{3-}$ is considered high when its concentration is more than $0.03 \mathrm{mg} / \mathrm{l}$ in water bodies as it causes the growth of algae dramatically, and then causes a problem of eutrophiction [9].

For heavy metals generally all analyzed metals showed a low concentration as shown in Table 2 and Figure 6. 
Table 1. $\mathrm{pH}$ and EC, $\mathrm{NO}_{3}^{-}$and $\mathrm{PO}_{4}^{3-}$ concentrations for surface water samples at the investigated area.

\begin{tabular}{|c|c|c|c|c|}
\hline Site & pH & $\mathrm{EC}(\mu \mathrm{s} / \mathrm{cm})$ & $\mathrm{NO}_{3}^{-} \quad(\mathbf{m g} / \mathbf{l})$ & $\mathrm{PO}_{4}^{3-} \quad(\mathrm{mg} / \mathrm{l})$ \\
\hline $\mathrm{S}_{1}$ & 7.2 & 491 & 0.18 & 0.44 \\
\hline $\mathbf{S}_{2}$ & 7.3 & 1116 & 0.49 & 0.43 \\
\hline $\mathrm{S}_{3}$ & 7.4 & 1659 & 0.52 & 1.24 \\
\hline $\mathrm{S}_{4}$ & 7.4 & 1433 & 1.07 & 2.16 \\
\hline $\mathrm{S}_{5}$ & 7.5 & 1929 & 4.16 & 2.02 \\
\hline $\mathrm{S}_{6}$ & 7.4 & 943 & 4.79 & 1.56 \\
\hline $\mathbf{S}_{7}$ & 7.5 & 2787 & 4.34 & 1.16 \\
\hline $\mathbf{S}_{8}$ & 7.6 & 1963 & 3.19 & 0.44 \\
\hline $\mathrm{S}_{9}$ & 7.8 & 1055 & 1.07 & 0.39 \\
\hline$S_{10}$ & 7.5 & 612 & 0.55 & 0.25 \\
\hline
\end{tabular}

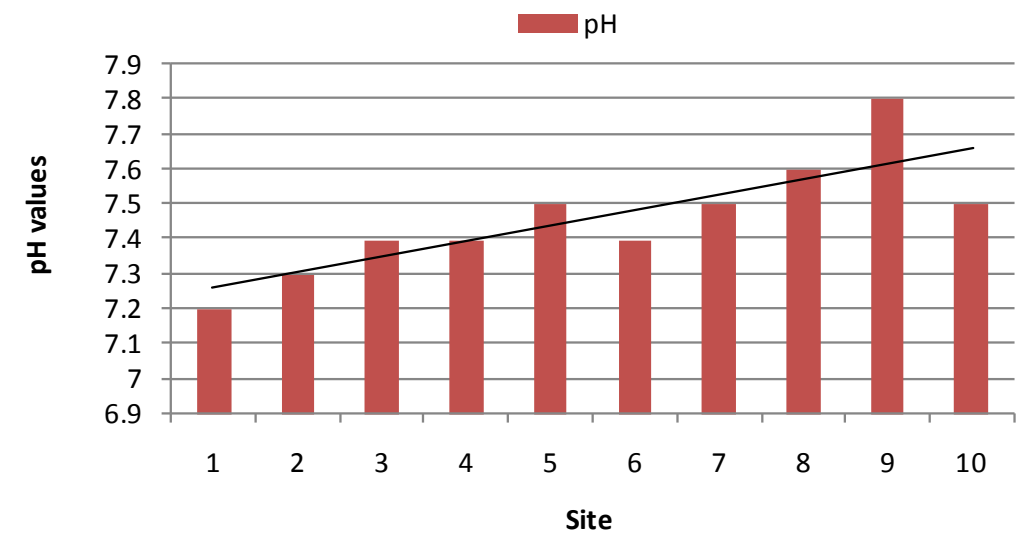

Figure 3. Acidity of surface runoff from different sites in the investigated area.

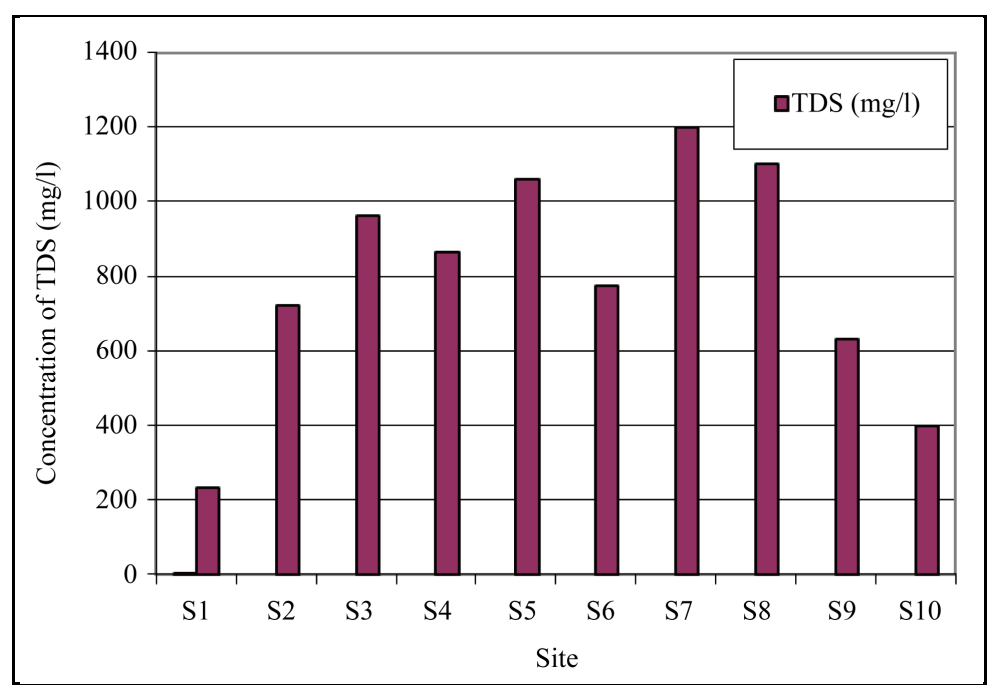

Figure 4. The average of TDS concentration (mg/l).

This can be attributed to either it is low at source or the slightly alkaline water enhance its precipitation on the solid phase rather being dissolved in the collected samples. Manganese showed the highest concentration among the analyzed heavy metals which is attributed the use of unleaded fuel which contains $\mathrm{Mn}$ in the form of Methylcyclopentadienyl manganese tricarbonyl. Based on carcinogenic effect of cadmium, Cd was classified in 


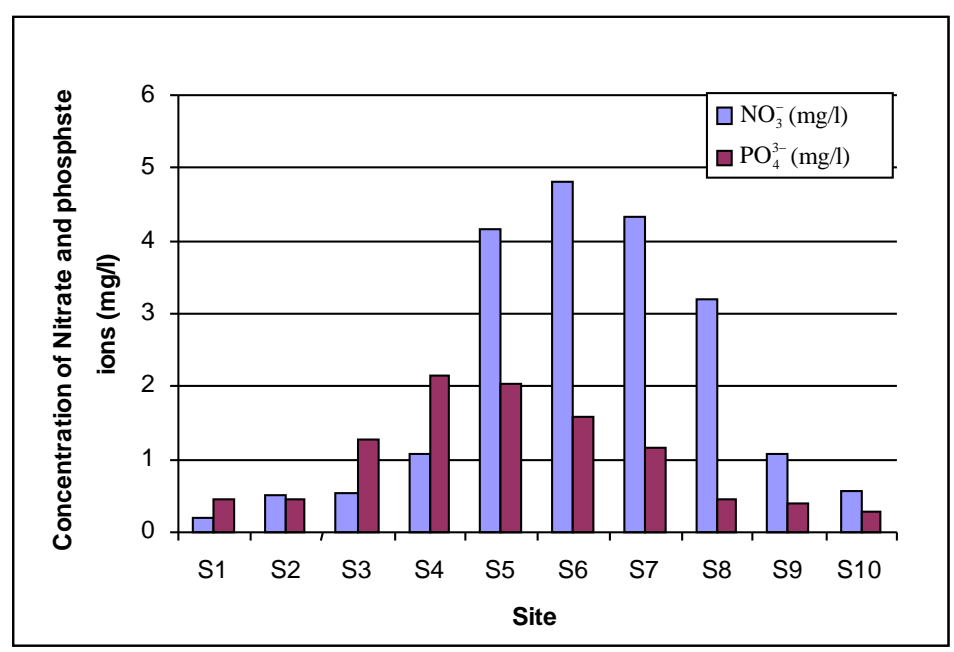

Figure 5. The average of $\mathrm{NO}_{3}^{-}$and $\mathrm{PO}_{4}^{3-}$ in $\mathrm{mg} / \mathrm{l}$ from different sites of the investigated area.

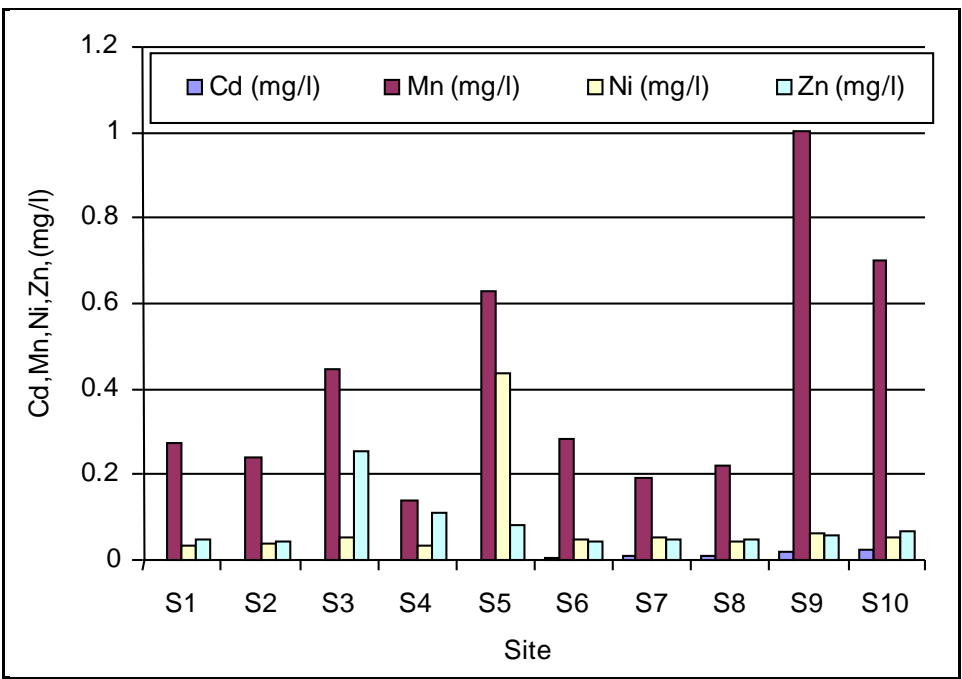

Figure 6. The rate of heavy metals (Cd, Mn, Ni, Zn) concentration (mg/l).

Table 2. Average of the heavy metals concentrations in ppb for water samples collected from different sites of the investigation area.

\begin{tabular}{ccccc}
\hline Site & Cd & Mn & Ni & Zn \\
S1 & 0.5 & 275.5 & 32 & 46.5 \\
S2 & 1.5 & 239.5 & 38.5 & 41.5 \\
S3 & 1.5 & 445.5 & 55.5 & 254.5 \\
S4 & 2 & 137.5 & 35 & 110.5 \\
S5 & 2 & 628 & 43.5 & 86 \\
S6 & 4.5 & 284 & 46.5 & 44 \\
S7 & 8.5 & 191.5 & 51.5 & 46.5 \\
S8 & 10.5 & 219 & 43 & 50.5 \\
S9 & 19 & 1003 & 66 & 61 \\
S10 & 22.5 & 696.5 & 59.5 & 69 \\
\hline
\end{tabular}


group (A2) of genes by the International Agency for Cancer Research on Cancer [10] [11]. For Cd, it showed low concentrations but the highest values were found at the mouth of the camp indicting a source from the camp area.

For Ni and Zn there was no significant variation between the sites indicating that the probable source of these metals is from natural origin and not from anthropogenic activities inside the camp area.

\subsection{Biological Analysis Results}

\subsection{1. $\mathrm{BOD}_{5}$ and $\mathrm{COD}$}

Table 3 and Figure 7 show that there is pollution in the surface water. COD concentration was high at the beginning of the camp in sites (S1-S2) due to the use of chemical organic substances which are not analyzed by bacteria, the values of COD in surface water in the study area ranged between $256 \mathrm{mg} / \mathrm{l}$ in site (S7) to $276 \mathrm{mg} / \mathrm{l}$ in site (S2). COD values were vary between the study sites because of different human activities and accumulation of wastes that contain different organic materials and the running of rain water which is laden with pesticides coming from farms that surround the camp. With regard to BOD, it was observed that there was an increase inside the camp in site (S5), as the concentration of $\mathrm{BOD}_{5}$ was $50 \mathrm{mg} / \mathrm{l}$ because of the inhabitants' intensity and their organic remnants. BOD was high inside the camp in site (S6-S7) because of the presence of swampy water that is mixed with sewage, and water used for washing pots that is rich with the chemical materials. COD is high outside the camp in site (S9) because of the running of rain water which mixed swampy water, Figure 7 and Table 3 show the concentration of $\mathrm{BOD}_{5}$.

Table 3. Shows the concentration of (COD-BOD 5 ) mg/l, Total Coliforms and Escherichia for surface water.

\begin{tabular}{ccccccc}
\hline & & & \multicolumn{2}{c}{ Group A } & \multicolumn{2}{c}{ Group B } \\
\cline { 4 - 6 } $\mathrm{S}_{1}$ & 25 & 448 & $>2419.6$ & E. coli & Total Coliform & E. coli \\
$\mathrm{S}_{2}$ & 25 & 576 & $>2419.6$ & $>2419.6$ & $>2419.6$ & 121.1 \\
$\mathrm{~S}_{3}$ & 20 & 384 & $>2419.6$ & $>2419.6$ & $>2419.6$ & 214.2 \\
$\mathrm{~S}_{4}$ & 30 & 384 & $>2419.6$ & 1732.9 & $>2419.6$ & 84.2 \\
$\mathrm{~S}_{5}$ & 50 & 448 & $>2419.6$ & $>2419.6$ & $>2419.6$ & 56.3 \\
$\mathrm{~S}_{6}$ & 40 & 384 & $>2419.6$ & $>2419.6$ & $>2419.6$ & 2.0 \\
$\mathrm{~S}_{7}$ & 45 & 256 & $>2419.6$ & $>2419.6$ & $>2419.6$ & 23.5 \\
$\mathrm{~S}_{8}$ & 25 & 192 & $>2419.6$ & $1413.6 \mathrm{Mpn} / \mathrm{wml}$ & $>2419.6$ & 29.5 \\
$\mathrm{~S}_{9}$ & 34 & 310 & $>2419.6$ & $135.4 \mathrm{Mpn} / \mathrm{wml}$ & $>2419.6$ & 8.3 \\
$\mathrm{~S}_{10}$ & 25 & 370 & $>2419.6$ & $>2419.6$ & $>2419.6$ & 2.0 \\
\hline
\end{tabular}

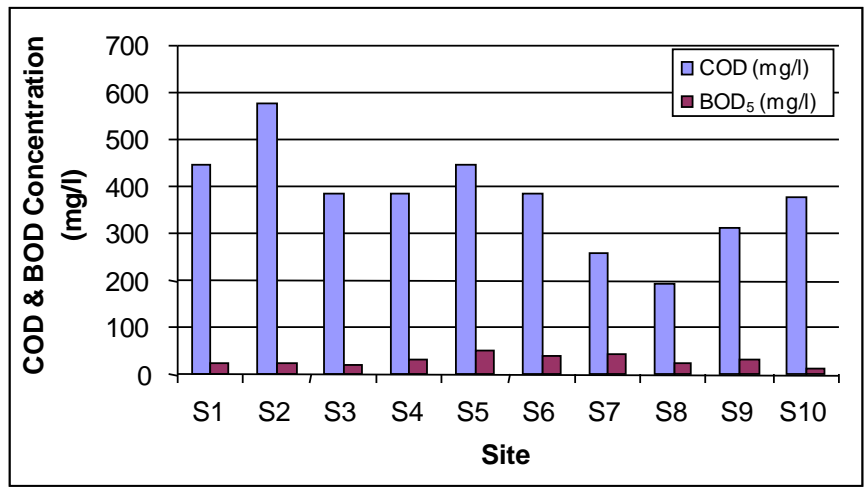

Figure 7. The (COD-BOD 5 ) concentration for surface water. 


\subsubsection{Total Coliforms and Esherichia coli}

The presence of Microorganisms in drinking water is considered as very dangerous; the pollution of surface water can be easy, because of its exposure to the atmosphere and the activities of other species. Groundwater is naturally protected under the rocks layers. Therefore, it is not exposed to microorganisms especially deep underground water. There is a possibility for shallow underground water and water springs to be polluted. The various properties of the study area, encourages the conducting of micro-organic tests in order to prevent the microorganism pollution for drinking water of the wells inside and surrounding the camp. The study area is popular of cracked solid basaltic rocks with high permeability to surface water. In addition, the spread of absorbent holes to discharge human wastes was the motivation behind conducting a microorganism test for surface and underground water.

Mirco-organic tests were done for two types of bacteria that its presence in surface and underground water is an indication of microorganism pollution caused by human remnants, waste water and industrial remnants. Test were conducted during the period of the study by two tests of each sample, the following types were tested:

- Total Coliform

- E. coli

During the laboratory results of bacteria tests within the period of the study, it was discovered that there is pollution in surface water, particularly inside Alza'tari camp in Group (A); gray water inside the camp indicates that waste water has reached to the surface.

With regard to Group (B) of E. coli bacteria, it declined in the sites inside and outside the camp because rains erode soil that contains microbes. All the sites are polluted with Total Coliform because of throwing remnants among the tents, unlicensed restaurants and waste water, Table 3 shows the Microbial Analysis of surface water.

\section{Conclusion and Recommendations}

Based on the above results it can be concluded that Za'atari camp can be considered as a source of pollution for the camp area as well as for the surrounding areas as the concentrations of all analyzed elements were found to be high at the camp area. Pollution from the camp just started but it might have an impact on underlying groundwater quality in the future if it is not handled properly. Hence, it is recommended to:

1) Establish a local waste water treatment plant to avoid using septic tanks,

2) Conduct environmental awareness programs for the refuges to stop disposing of:

a) Household chemicals or cleaning agents down the sink or toilet;

b) Grey water on the ground between tents and caravans;

c) Pills, liquid or powder medications or drugs down the toilet, car oil and battery liquids on the ground.

\section{References}

[1] Tarawneh, K., Qteitat, M., Mraiat, Gh. and Jiries, A. (2000) Hyrdochemical and Bacteriological Study of the Springs in Al-Tafila Region/South Jordan. Mutah J. for Res. and Studies, 15, 25-46.

[2] Al-Kharabsheh, A.A. (1999) Influence of Urbanization on Water Quality at Wadi Kufranja Basin (Jordan). Journal of Arid Environments, 43, 79-89. http://dx.doi.org/10.1006/jare.1999.0534

[3] Alsagrat, B. (1997). Determining the Concentrations of Heavy Metals in the Groundwater Basin of Amman-Zarqa. MA Thesis, University of Jordan, Amman.

[4] Alzoubi, K. (2000) Geochemical and Environmental Aspects of the Soil and Groundwater in Northeastern of AlMafraq.

[5] Al-Ani, M. (2001) Chemical and Microbial Quality of Drinking Water in AL-Mafraq Area. MS Thesis, Al-Albyt University, Mafraq.

[6] Al-Harahsheh, A., Alfaragat, M., Alshdeifat, F. and Al-Harahsheh, S. (2011) The Study of Chemical Evolution and Indicators in the Quality of Drinking Water from the Source to the Consumer for the Cities of Mafraq and Zarqa. Al AlBayt University, Mafraq.

[7] American Public Health Association (2012) Standard Method for the Examination of Water and Wastewater. 20th Edition, American Public Health Association, Washington DC.

[8] Ibid.

[9] Lee, A.J. and Lee, G.F. (2005) Eutrophiction (Excessive Fertilization) Water Surface and Agricultural Water. Wiley, 
107-114.

[10] WHO (2003) Jordan Standard of Drinking Water (JS). WHO, Geneva.

[11] World Health Organization (2003) Cadmium in Drinking - Water Background Document Preparation of WHO Guidelines for Drinking —Water Quality. Geneva Health Organization (WHO), Geneva. 
Scientific Research Publishing (SCIRP) is one of the largest Open Access journal publishers. It is currently publishing more than 200 open access, online, peer-reviewed journals covering a wide range of academic disciplines. SCIRP serves the worldwide academic communities and contributes to the progress and application of science with its publication.

Other selected journals from SCIRP are listed as below. Submit your manuscript to us via either submit@scirp.org or Online Submission Portal.
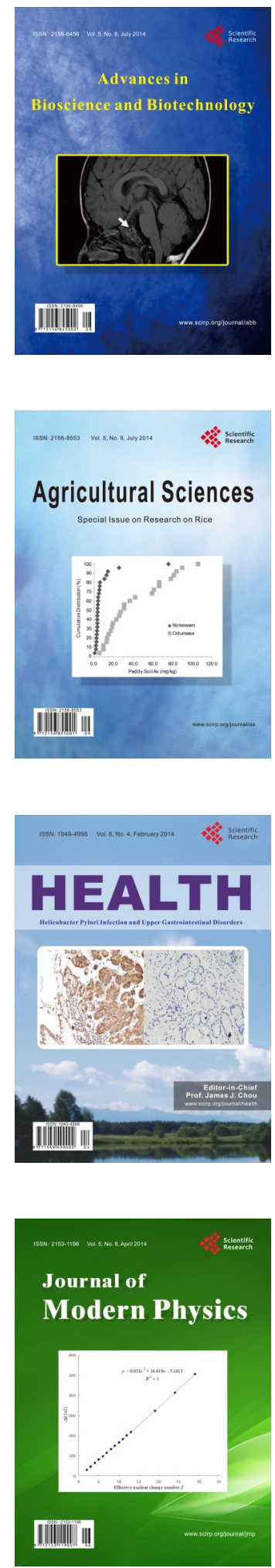
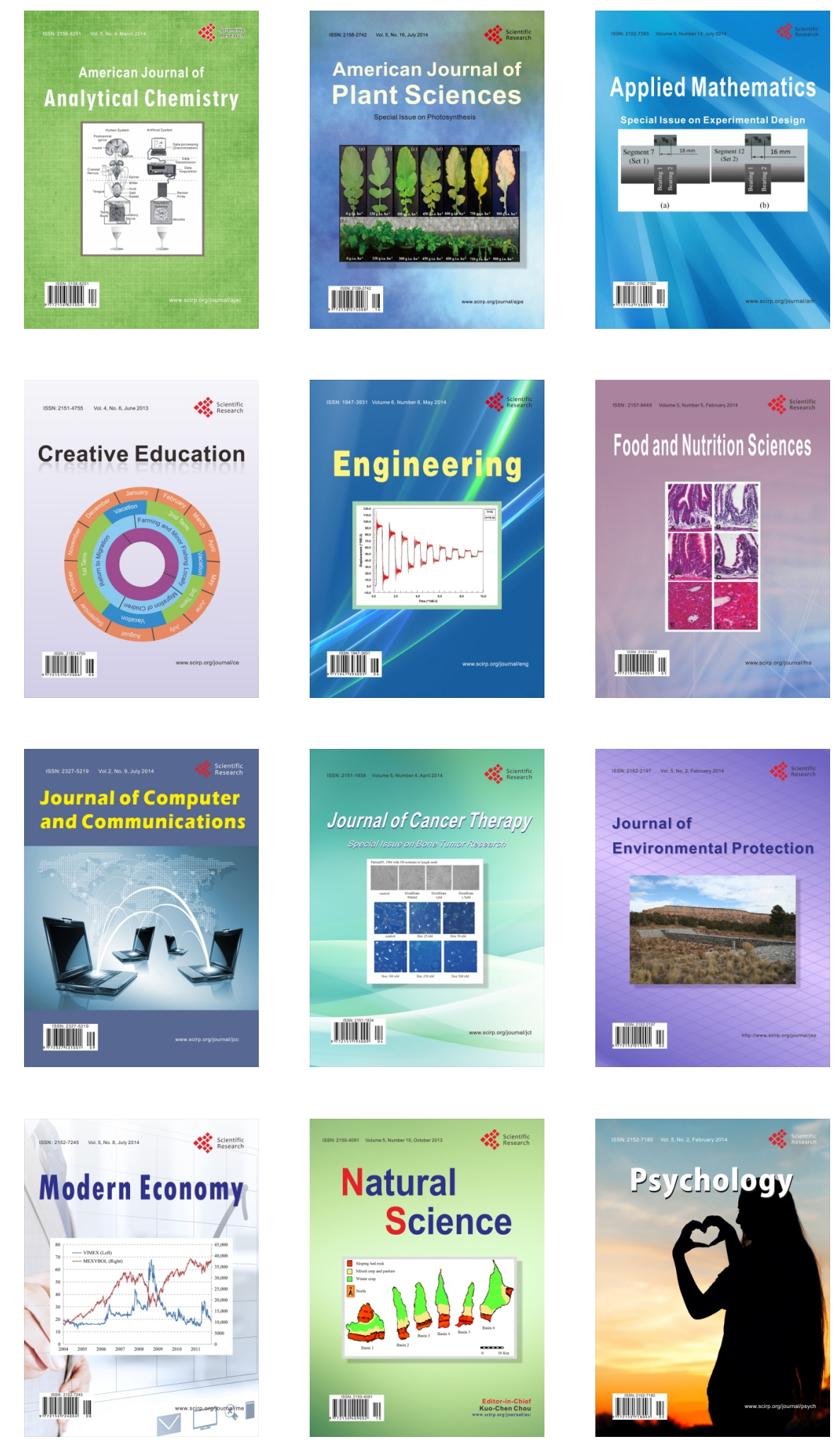